\title{
The Role of Magmatic Loads and Rift Jumps in Generating Seaward Dipping Reflectors on Volcanic Rifted Margins
}

W. Roger Buck

\begin{abstract}
The largest volcanic constructs on Earth are the seismically imaged seaward dipping reflector (SDR) units found offshore of many rifted continental margins, including most that border the Atlantic Ocean. Whether their formation requires large magnitude (i.e. $10 \mathrm{~s}$ of $\mathrm{km}$ ) of normal fault slip or results from the deflection of the lithosphere by the weight of volcanic flows is controversial. Though there is evidence for faulting associated with some SDRs, this paper considers the range of structures that can be produced by magmatic and volcanic loading alone. To do this an idealized mechanical model for the construction of rift-related volcanic flow structures is developed. Dikes open as plates move away from the center of a model rift and volcanic flows fill the depression produced by the load caused by dike solidification. The thin elastic plate flexure approximation allows a closed form description of the shape of both the contacts between flows and between the flows and underlying dikes. The model depends on two independent parameters: the flexure parameter, $\alpha$, and the maximum isostatically supported extrusive layer thickness, $w_{0}$. For reasonable values of these parameters the model reproduces the observed down-dip thickening of flows and the range of reflector dip angles. A numerical scheme using the analytic results allows simulation of the effect of temporal changes in the locus of magmatic spreading as well as changes in the amount
\end{abstract}


24 of volcanic infill. Either jumps in the location of the center of diking or periods with no

25 volcanism result in separate units or "packages" of model SDRs, in which the flow-dike

26 contact dips landward, consistent with observations previously attributed only to listric

27 normal fault offset. When jumps in the spreading center are small (i.e. less than $\alpha$ ) they

28 result in thicker, narrower volcanic units on one side of a rift compared to those on the

29 other side. This is similar to the asymmetric distributions of volcanic packages seen

30 across some conjugate margins.

31 Keywords: Volcanic Margins; Continental Rifting; Seaward Dipping Reflectors; Flexure 


\section{1. Introduction}

33 Most continental breakup events are preceded by massive extrusion of basalts comprising

34 Large Igneous Provinces (LIPs) often located near the central part of a rift system

35 (Courtillot et al., 1999). LIP volcanics were first identified on land where they typically

36 are distributed on lateral dimensions of $\sim 1000 \mathrm{~km}$ and have volumes of several million

37 cubic kilometers (Coffin and Eldholm, 1994). The discovery of Seaward Dipping

38 Reflectors (SDRs) greatly expanded the estimated lateral dimensions and volumes of rift-

39 related volcanics. SDRs are sequences of seismically bright reflectors up to $\sim 10 \mathrm{~km}$ thick

40 and $\sim 100 \mathrm{~km}$ wide were first identified on extension-parallel multi-channel seismic

41 profiles crossing the rifted continental margins of the South and North Atlantic (Hinz,

42 1981, Mutter et al., 1982). The reflectors dip toward the ocean and bound layers that

43 thicken down-dip. Although SDRs are usually buried under thick layers of sediment

44 (Figure 1) drilling shows that they are made up of volcanic flows interleaved with

45 sediments (Larson et al., 1994). Volcanic rifted margins (Figure 1A), defined by SDRs,

46 are also underlain by regions with high seismic velocity, thought to indicate magmatic

47 lower crust intruded at the time of SDR extrusion (Holbrook and Kelemen, 1993). SDRs

48 have been found along one to two thousand kilometer-long sections of margins adjacent

49 to LIPs and the total amount of intruded and extruded magma associated with a given

50 breakup event can approach 10 million of cubic kilometers (Franke, 2013).

51 The finding of widespread SDRs has energized the debate about whether massive input

52 of magma, likely resulting from mantle plumes, is needed to allow rifting. Before the

53 recognition that most rifted margins are volcanic it was generally accepted that rifting

54 occurred by amagmatic lithospheric stretching involving faulting of the brittle crust and 
55 ductile flow of the warmer parts of the crust and mantle (e.g. McKenzie, 1978).

56 Stretching explained how rifted continental margins subsided to produce space for thick

57 piles of shallow water sediment. Yet the force needed for such tectonic stretching of

58 lithosphere is estimated to be as much as ten times greater than the forces that may be

59 available to drive rifting (Kusznir and Park, 1984, Naliboff et al., 2012). Since magma

60 can allow lithospheric splitting, heating and thinning at far lower stress levels than

61 needed for faulting (e.g. Rivalta et al., 2014), the inclusion of magma into rifting models

62 offered a way to rift continents at modest force levels (Buck, 2004; Bialas et al., 2010).

63 A consequence of these models is that the tectonically accommodated fraction of plate

64 separation should be small in a magma-rich environment, thereby precluding the

65 formation of large-offset normal faults. Indeed, only very small offset $(\sim 10 \mathrm{~m})$ normal

66 faults are found in the magmatically robust regions of Iceland, primarily in areas of

67 abandoned rift segments (e.g. Garcia et al., 2003, 2008; Siler and Karson, 2012). Many

68 groups, however, have inferred a central role for faulting in the formation of SDRs based

69 on the landward dip of the base of some seismically imaged volcanic units (Gibson and

70 Love, 1989; Planke et al., 2000; Geoffroy, 2005; Quirk et al., 2014; and see Figure 1C).

71 According to this 'volcanic faulting model' extrusive basalts fill the depression created

72 by 10's of kilometers of offset of a normal fault bounding a half-graben, in much the

73 same way syn-rift sediment fills magma-poor extensional basins (Figure 2A). Geoffroy

74 (2005) has marshaled many observations that favor a role for normal faults that dip

75 landward in SDR formation, including the observation of landward dipping faults cutting

76 in sections of basalt flows exposed on land in Eastern Greenland. However, a landward

77 dip is opposite to what is seen for most rift-bounding and continental margin normal 
78 faults (Sibuet, 1992) and expected from analog (Brun, 1999) and numerical rift models

79 (Huismans et al., 2005). A numerical model by Geoffroy et al. (2015) produces faults

80 that dip landward but only by assuming a complex initial lithospheric structure and

81 evolution.

82 Further evidence of a role for tectonic faults in volcanic margin formation is inferred

83 from the asymmetric distribution of some SDRs packages across conjugate rifted

84 margins. For example, along a portion of the South Atlantic margins Becker et al. (2016)

85 identify two to three SDR packages on seismic lines crossing each conjugate margin (see

86 Figure 1D and 1E). Up to a hundred kilometers of slip on lithosphere-scale normal

87 "detachments" has been suggested as a way to produce thicker and narrower volcanic

88 units on the Argentinean side compared to the South African side (Becker et al., 2016).

89 Similar large-offset detachments have been suggested to explain the structure of other

90 volcanic margins (e.g. Pindell et al., 2014).

91 Though faulting may play a role in the development of some SDRs, the object of this

92 paper is to consider what volcanic structures can be produced during rifting without

93 large-offset faults. The quantitative mechanical model developed here builds on

94 previous, largely kinematic, models of the development of SDRs. An analytic

95 description of the response of the lithosphere to the loads of dike solidification and

96 volcanic flows is developed. This description is then used to show that jumps of the

97 center of spreading and volcanism can result in volcanic flow unit geometries that are

98 similar to those observed at some volcanic rifted margins. The formulation developed

99 here can form the basis of more rigorous numerical models of the development of

100 volcanic rifted margins. 


\section{2. Previous Work on the Formation of SDRs due to Volcanic Loading}

102 The earliest interpretation of SDRs was based on observations of the structure of massive

103 basalt flows that dip toward the subaerial spreading center on Iceland (Mutter et al.,

104 1982). Glacially carved fjords provide a window into these volcanic piles and show that

105 the layers dip toward the center of the island. This led (Bodvardsson and Walker, 1964)

106 to develop a 'volcanic loading model' that required plate spreading even before plate

107 tectonics had been widely accepted. Their model assumes local isostatic compensation of

108 volcanic flows fed by dikes opening repeatedly close to a plate-spreading center. The

109 flows are assumed to be thickest close to the axis of diking and to have a triangular cross-

110 section. This explains the increasing dip of volcanic flows with depth as well as the

111 down-dip thickening of volcanic flows seen on Iceland and for SDRs.

112 Based on the qualitative arguments of Bodvarsson and Walker (1964), Palmasson, (1980)

113 developed a kinematic model for the development of multiple volcanic flows assuming

114 local isostasy and a particular geometry of volcanic extrusion. To go from kinematic to

115 dynamic models requires specification of loads that produce surface lowering and so

116 space for extrusives to fill. Four ideas about the origin of such loads have been

117 suggested. The effect of the load of a migrating volcanic construct on lithospheric flexure

118 was treated by by Watts and Cox (1989) to explain the geometry of down-dip thickening

119 of basalt flows seen for the Deccan Traps. Bastow and Keir (2011) suggest that the

120 thinning of the ductile lower crust by stretching causes isostatic subsidence that allows

121 infilling by extrusives. Pindell et al (2014) suggest that emptying of a magma chamber

122 should pull down the surface. Finally, Corti et al. (2014) show that intrusion of dense

123 mafic rocks into a felsic crust can flex the upper crustal lithosphere and make space for 
124 the kinds of volcanic structures observed in parts of the East African Rift System. All of

125 these processes may act at a volcanic margin, but are difficult to incorporate in a simple,

126 general model with a minimum of free parameters. As in Corti et al. (2014) the model

127 described below focuses on the effect of mafic dike intrusions that are seen to

128 accommodate plate separation at volcanic rifts. However, in the new model flexure is

129 driven by the density increase on solidification of series of basaltic dikes that fill in the

130 space produced by plate separation. Combined with simplifying assumptions about

131 magma extrusion and thin plate flexure, this allows derivation of an analytic description

132 of the geometry of resulting volcanic structures.

\section{3. Analytic model of 'Volcanic Flexure'}

134 When a basaltic dike solidifies the related density increase should load the lithosphere

135 and pull down the surface, creating space that can be filled in by extrusives. Derivation

136 of an analytic description of the geometry of extrusive flows resulting from such loading

137 and infill follows an approach used to treat dike solidification at a mid-ocean ridge,

138 without volcanic flows, that results in an axial high similar to those seen at fast spreading

139 ridges (Buck, 2001, Shah and Buck, 2001, 2004).

140 Fluid magma of density $\rho_{f}$ in a dike at the axis of rifting or spreading, at $x=0$, is taken to

141 rise to its level of local isostatic compensation (Figure 3a). As the dike solidifies it

142 becomes part of the adjacent lithospheric plates and as the density of the solid dike

143 increases to $\rho_{d}$ it loads and deflects the plates (Figure $3 \mathrm{~b}$ ). If the dike height $h_{d}$ is much

144 smaller than its along-axis length then a two-dimensional cross-sectional model,

145 involving vertical depth $z$ and horizontal distance $x$ from the center of dike injection, is 
146 justified. A dike of half-width $\delta x$ that solidifies from fluid magma will produce a load

147 per unit rift length on each plate of:

$\delta V_{0}=\delta x g h_{d} \Delta \rho_{d}$

148 where $\Delta \rho_{d}=\left(\rho_{d}-\rho_{f}\right)$ and $\mathrm{g}$ is the acceleration of gravity. Extrusives are assumed to fill

149 in and amplify the depression produced by the load of the solidified dike (Figure 3c).

150 Two approximations are needed to allow derivation of an analytic expression for the

151 deflection of the lithosphere by combined dike and extrusive loads. First, the lithosphere

152 is treated as a thin elastic plate (Watts, 2001) and, second, the region above the flexing

153 plate is treated as if it were an inviscid fluid with the density of the infilling material.

154 Assuming the plate has a laterally uniform rigidity $D$ the relevant form of the thin-plate

155 flexure equation for vertical deflection $w$ is then:

$D \frac{d^{4} w}{d x^{4}}+g \Delta \rho_{s} w(x)=0$

156 where the flexure parameter $\alpha=\left(4 \mathrm{D} / \mathrm{g} \Delta \rho_{s}\right)^{1 / 4}$ and $\mathrm{g}$ is the acceleration of gravity. $\Delta \rho_{s}$,

157 the compensation density contrast, is the difference between the density of substrate

158 material displaced by the deflected plate $\rho_{s}$ and the density of the infilling material $\rho_{i}$, so

159 that $\Delta \rho_{s}=\left(\rho_{s}-\rho_{i}\right)$.

160 The lithosphere at the axis, $x=0$, is broken by the dike so that the applied bending

161 moment and the effective plate rigidity there are zero. Then the dike solidification load

162 given by equation 1 applied at the axis produces vertical surface deflections:

$$
\delta w(x)=\delta w_{0} \exp \left(-\frac{x}{\alpha}\right) \cos \left(\frac{x}{\alpha}\right)
$$


163 where $\delta w_{0}=2 \delta V_{0} /\left(\alpha g \Delta \rho_{S}\right)=2 \delta x h_{d} \Delta \rho_{d} /\left(\alpha \Delta \rho_{S}\right)$.

164 Following Buck (2001) it can be shown that the repeated intrusion of an infinite number

165 of dikes with infinitesimal width results in relief of the tops of the dikes given by

166 integration of equation 3 from 0 to $x$, yielding:

$$
w_{t}(x)=w_{0}\left\{\exp \left(-\frac{x}{\alpha}\right)\left[\sin \left(\frac{x}{\alpha}\right)-\cos \left(\frac{x}{\alpha}\right)\right]+1\right\}
$$

167 where $w_{0}=h_{d}\left(\Delta \rho_{d} / \Delta \rho_{s}\right)$. The position of the top surfaces of individual extrusive flows

168 predicted by this model can also be described analytically assuming that the flow surface

169 originates at zero height (i.e. at the height of the top of the fluid dike at the axis). Then

170 the depth $w_{s}$ of a flow surface is given integration of equation 3 from $x$ - $x_{0}$ to $x$, giving:

$$
\begin{aligned}
w_{s}(x)=w_{0}\{ & \exp \left(-\frac{x}{\alpha}\right)\left[\sin \left(\frac{x}{\alpha}\right)-\cos \left(\frac{x}{\alpha}\right)\right] \\
& \left.\quad-\exp \left(-\frac{\left(x-x_{0}\right)}{\alpha}\right)\left[\sin \left(\frac{\left(x-x_{0}\right)}{\alpha}\right)-\cos \left(\frac{\left(x-x_{0}\right)}{\alpha}\right)\right]\right\}
\end{aligned}
$$

171 where $x_{0}$ is the horizontal distance from the axis to the contact between the flow and the

172 underlying dike. Figure 4 shows that this model produces a geometry of extrusive layers

173 that is similar to that observed for a sequence of flows in an SDR. The non-dimensional

174 axes of that plot emphasize that the results depend on two length scales: the flexure

175 parameter $\alpha$ and $w_{o}$.

176 The horizontal wavelength of lithospheric bending is set by the flexure parameter $\alpha$. For

177 the thin elastic plate approximation used in the present model the rigidity $D=E h^{3} / 12(1$ -

$178 v^{2}$ ) where $E$ is Young's Modulus, $h$ is the effective elastic thickness of the layer and $v$ is 
179 Poisson's ratio. For $h=5 \mathrm{~km}, E=5 \times 10^{10} \mathrm{~Pa}, v=0.25$ and $\Delta \rho_{s}=200 \mathrm{~kg} / \mathrm{m}^{3}$ the flexure

180 parameter would be $\sim 33 \mathrm{~km}$.

181 The vertical scale of the volcanic pile is controlled by $w_{0}$, which is equivalent to the

182 thickness of extrusives in local isostatic equilibrium with the fluid dike at the axis. In an

183 off-axis column extrusive infill of density $\rho_{i}$ overlies a solidified dike layer of height $h_{d}$

184 and density $\rho_{d}$ while an on-axis column consists of a fluid dike of height $h_{d}$ and

185 density $\rho_{f}$. The on- and off-axis regions are taken to float on a compensating layer of

186 density $\rho_{c}$ that is sufficiently weak that lateral pressure gradients are negligible. Having

187 the same overburden pressure at the base of the on- and off-axis columns implies that $w_{0}$

$188=h_{d}\left(\rho_{d}-\rho_{f} /\left(\rho_{c}-\rho_{i}\right)=h_{d}\left(\Delta \rho_{d} / \Delta \rho_{c}\right)\right.$, consistent with the flexural model derivation. This

189 illustrates that it is the increase in density of the solid dikes relative to the fluid dike at the 190 axis that results in a finite thickness of the extrusive layer.

191 The vertical deflections depend strongly on the density of the infilling material.

192 Assuming $h_{d}=10 \mathrm{~km}, \Delta \rho_{d}=200 \mathrm{~kg} / \mathrm{m}^{3}$, with zero density air as the infilling material (i.e.

193 for $\rho_{i}=0$ ) and taking $\rho_{c}=3000 \mathrm{~kg} / \mathrm{m}^{3}$ then $w_{0}$ would be $667 \mathrm{~m}$. With the same

194 parameters except with lava density as the infilling material (i.e. with $\rho_{i}=2800 \mathrm{~kg} / \mathrm{m}^{3}$ )

195 then $w_{0}$ would be $10 \mathrm{~km}$.

\section{4. The effect of rift axis jumps}

197 The analytic volcanic flexure model produces the same distribution of SDR flow units on 198 both sides of a model rift (Figures $3 \& 4$ ). The production of asymmetry may be

199 accomplished by offsets in the position of the center of diking such as those seen at 
200 spreading centers. For example, several offsets or jumps in the location of Icelandic

201 spreading centers are well documented and one is ongoing in southern Iceland where the

202 eastern rift zone is replacing the dying western rift zone (Hardarson et al., 1997).

203 Submarine ridge propagation produces offsets in the position of the spreading center on

204 length scales that are usually smaller than the jumps seen on Iceland and they can result

205 in asymmetries and gaps in the magnetic record of seafloor age (Hey, 1979). Several

206 processes may cause spreading center jumps including plume ridge offset (e.g

207 Mittelstaedt et al., 2011) as well as shifts in the spreading direction (e.g. Hey, 1979). An

208 illustration of how jumps can produce separate SDR packages in the context of volcanic

209 flexure is shown in Figure 2B.

210 Incorporation of such spreading center jumps requires numerical summation of the effect

211 of multiple small dike-extrusion events. To do this a uniform grid of points a distance $\delta x$

212 apart in the horizontal $\mathrm{x}$-direction are specified where cumulative vertical deflections

213 calculated using equation 2 are tallied. If each dike has a width of $2 \delta x$ then dike opening

214 offsets all grid points by one unit. A model time-step involves adding the incremental

215 deflection induced by dike solidification and volcanic infilling, and then laterally

216 offsetting the grid point values by $\delta x$.

217 Two length scales have to be specified to simulate jumps: the width, $\Delta \mathrm{x}_{\mathrm{ext}}$, of the

218 extrusive packages on each side of the rift between jumps and the horizontal distance of a

219 jump, $\Delta \mathrm{x}_{\mathrm{jump}}$. Jumps are accomplished by reassignment of the location of the numerical

220 center of spreading relative to the marker points defining extrusive layers. To illustrate

221 the structure of the extrusives a new set of markers is added periodically at a depth $=0$, 
222 approximating the surface of an extrusive flow. Jumps can result in separate packages of

223 flows that may overlap. Results of a model case with particular values of $\Delta \mathrm{x}_{\mathrm{ext}}$ and $\Delta \mathrm{x}_{\mathrm{jump}}$

224 are shown in Figure 5B.

\section{5. The effect of gaps in extrusion}

226 Separate SDR units could also be produced if there were periods with dike

227 accommodated spreading but little or no extrusion. The existence of gaps in extrusion at

228 spreading centers is more speculative than the existence of jumps, but gaps in extrusion

229 are included here for completeness. There is evidence from the spreading segment at

$23016^{\circ} \mathrm{N}$ on the East Pacific Rise (EPR) that the volcanic flux may first increase and later

231 decrease after a ridge jump. There the axial high formed after a ridge jump occurred (at

232150 to $300 \mathrm{Ka}$ ) is much higher than is typical for fast spreading ridges and apparently

233 higher than the high that was abandoned (Carbotte et al., 2000; Shah and Buck, 2005).

234 To simulate gaps an extrusive phase of width $\Delta \mathrm{x}_{\text {ext }}$ is followed by a phase of width $\Delta \mathrm{x}_{\text {gap }}$

235 with no extrusive loading during which an infill density of zero is specified. Figure 5C

236 shows a case with 3 overlapping packages of extrusive layers produced by assuming

237 alternating extrusive and gaps phases and markers are not added during a gap phase. If

238 the gap phase is wider than about twice the flexure parameter the packages do not

239 overlap.

\section{6. Discussion}

241 A cursory comparison of model predictions (Figures 4 and 5) with the seismic reflection

242 images of SDRs in Figure 1 shows that the model produces the general shape and 
243 inferred internal structure of for a range of SDR packages. The analytic version of this

244 model allows clear illustration of the relations between model parameters and predictions

245 that can be tested with observations. For example, the maximum slope of the base of the

246 flows is $2 w_{o} / \alpha$, and the dips equal $\arctan \left(2 w_{o} / \alpha\right.$.). For $w_{0}=5-10 \mathrm{~km}$ and a flexure

247 parameter $\alpha$ of $20-60 \mathrm{~km}$ the predicted maximum dips range from 10 to 45 degrees which

248 is comparable to or wider than the observed range.

249 The predicted thickness of the extrusive pile depends on the height of the intruded dike

250 and the density at a depth of compensation of the loads. The height of dike opening

251 should be close to the thermally-controlled thickness of brittle lithosphere in a rift and

252 this is difficult to estimate for a given rift. Based on the observed depths of seismicity

253 during dike intrusion events along the volcanic rich, slowly spreading ridge in Iceland

254 (Einarsson and Brandsdottir, 1980) a reasonable value of the dike height $h_{d}$ is $10 \mathrm{~km}$. If

255 the lower crust is very weak then compensation can occur there, otherwise compensation

256 should occur in the mantle. For $h_{d}=10 \mathrm{~km}$ and compensation of the loads in the lower

257 crust, with a substrate density $\rho_{s}$ of $3000 \mathrm{~kg} / \mathrm{m}^{3}$, the model gives $w_{0} \sim 10 \mathrm{~km}$, assuming an

258 infill density $\rho_{i}$ of $2800 \mathrm{~kg} / \mathrm{m}^{3}$ and an increase in dike density on solidification $\Delta \rho_{d}$ is 200

$259 \mathrm{~kg} / \mathrm{m}^{3}$. With the same parameters except with compensation in mantle, with $\rho_{s}=3300$

$260 \mathrm{~kg} / \mathrm{m}^{3}$, the SDR package would be as thin as $4 \mathrm{~km}$. Thus, thick SDRs may imply that the

261 lower crust was weak enough to flow easily at the time of their emplacement.

262 To produce the asymmetry in the thickness and width of SDRs requires several jumps in

263 location of the center of diking and that the distance of the jumps is smaller than the 
264 flexure parameter $\alpha$. Figure 6 compares a particular model with three small jumps to

265 interpreted sections of SDRs for conjugate South Atlantic margins.

266 Jumps that are larger than $\alpha$ should result in thicker extrusive piles on both sides of the

267 new center of diking. Such large-scale jumps have happened on Iceland (Hardarson et

268 al., 1997) and this model makes the potentially testable prediction of thicker extrusives

269 on both sides of the region where a new center of spreading formed, as shown in Figure

2707.

271 The large $(\sim 100 \mathrm{~km})$ jumps on Iceland are likely related to migration of the spreading

272 center away from a plume, as noted earlier. The small jumps required to produce

273 asymmetries across volcanic rifted margins in the context of this model may be related to

274 offsets of the pole of opening. The geometry of some rifts and margins seems to indicate

275 such offsets. For example, the present direction of opening of the Red Sea is not

276 orthogonal to the overall trend of the rift change (Mohriak and Leroy, 2012). If the early

277 rift opening weakened the lithosphere and set the rift trend then the present geometry

278 might reflect a shift in the opening direction.

279 Either jumps in the spreading center or gaps in extrusion can lead to separate SDR

280 packages that look similar to those predicted by faulting models. The fact that a

281 combination of dike solidification and volcanic loads can produce many of the features

282 that have been attributed to faulting does not necessarily mean that faulting plays no role

283 in the formation of SDRs. There is observational evidence, both on land and from

284 seismic records (Geoffroy, 2005) that faulting does accompany volcanic flow structures.

285 One of the most promising ideas about how this could happen is the suggestion by Quirk 
286 et al. (2014) that an axial horst, underlain by low-density partial melt may be bordered by

287 outward dipping normal faults. Two-dimensional numerical simulations of this

288 conceptual are being formulated.

289 More work needs to be done to justify the assumptions and simplifications of the present

290 model. To allow an analytic description, extrusives are assumed to be present not only in

291 the flexural depression near the spreading axis but also above the flanking flexural bulge.

292 This approximation leads to a larger flexural bulge than would exist if extrusives only

293 filled in the flexural depression. Numerical treatment of a thin plate elastic model with

294 extrusive infill only to the level of the spreading axis show that simplifying

295 approximation changes the predicted dip and thickness of the beds by only a few percent.

296 Also, there has to be some topographic slope for lava to flow away from the axis, but a

297 zero slope is assumed in the model. One reason is that flows in continental flow basalt

298 provinces form with very low surface slopes, as low as 0.01 (Keszthelyi and Self, 1998).

299 Assuming a finite slope greatly complicates the model and adds a poorly constrained 300 parameter.

301 Another limitation of the thin plate flexure model is that it can only describe vertical 302 deflections and so the rotations of vertical planes that should occur as a plate is bent are 303 not treated. Rotations of the initially horizontal flows are well approximated and dikes

304 should be orthogonal to the flows at their contact as indicated in the model schematic of

305 Figure 3. The precise rotation of dikes and flows can only be accurately treated with a

306 two-dimensional model. 
307 In addition, the finite strength of the lithosphere can result in yielding of the top and

308 bottom of a bending plate and this reduces the plate rigidity and so the wavelength of

309 flexure decreases as loads and bending increase (e.g. Bodine et al., 1981). The analytic

310 model predicts curvatures of order $10^{-5} \mathrm{~m}^{-1}$ and these would suggest elastic stresses of

311 greater than a GPa and these would certainly cause brittle failure of parts of the

312 lithosphere. Fully, two-dimensional elasto-plastic models of lithospheric bending under

313 large loads suggest that the effective elastic thickness of a finite-strength brittle layer may

314 only be a fraction of its true thickness (e.g. Lavier et al., 2000). Thus, the appropriate

315 values of the flexure parameter should be much smaller than for a purely elastic plate of a

316 given thickness.

317 A two-dimensional version of this model with more realistic lithospheric rheologies

318 could better treat the strong bending that should result in brittle yielding of the

319 lithosphere via distributed faulting. One question worth study is whether bending related

320 faulting could explain the observed small offset faulting seen in the coastal flexure zone

321 of Greenland and previously used as evidence for a key role of faulting in SDR formation

322 (e.g. Geoffroy, 2005). Another key question to be addressed with a more complete model

323 is the rapid subsidence of a volcanic passive margin (Pindell et al., 2014). One

324 possibility to be tested is whether a reduction in the rate of magma input would lead to

325 the kind of crustal thinning during continued rifting that has been suggested by Bastow

326 and Keir (2011). However, the main conclusion of the present work, that some volcanic

327 margin structures can be produced without faulting, is unlikely to be altered by more

328 advanced work. 
329 Some questions about SDR formation will require consideration of very large-scale

330 geodynamic processes. For example, at many volcanic rifted margins there is evidence

331 of separate inner and outer SDRs. One can speculate that the early (inner) phase of SDR

332 formation may reflect melt production by active flow in a plume or plume head that is

333 focused in a region of LIP formation. Transport of this early forming magma from the

334 locus of LIP formation to erupt along the rift axis might be accomplished via dikes. The

335 later (outer) SDRs might reflect passive upwelling of hotter-than-normal mantle and

336 vertical transport of resulting melts in the way envisioned by White and McKenzie

337 (1989).

\section{7. Conclusions}

339 Numerous authors suggest that many kilometers of normal fault offset are needed to

340 provide the space for the thick volcanic flows comprising the seaward dipping reflector

341 sequences that define volcanic rifted margins (Gibson and Love, 1989; Planke et al.,

342 2000; Geoffroy, 2005; Quirk et al., 2014). This view challenges our understanding of the

343 basic mechanics of magma intrusion during rifting. Theory predicts that if sufficient low-

344 viscosity basaltic magma is always available for extrusion that extensional stresses

345 should not reach the level needed for lithosphere-cutting normal faults (e.g. Rivalta et al,

346 2015). Observations in areas of massive sub-aerial basaltic volcanism, like Iceland,

347 suggest that ridge-ward dipping volcanic flow structures, similar to SDRs, can form

348 without major normal fault offsets (e.g. Bodvarsson and Walker, 1964).

349 This paper shows that several SDR-related structures, often attributed to faulting, can be 350 produced by magmatic and volcanic loading alone. In the quantitative "volcanic flexure"

351 model derived here the space for volcanic flows results from the load of magmatic dikes 
352 solidifying and densifying after emplacement at a rift center (Figure 2). This description

353 of the mechanics of rift magmatism builds directly on the kinematic models of volcanic

354 flow loading (Bodversson and Walker, 1964, Palmasson (1980) that were inspired by

355 observations of ridge-ward thickening sequences of lava flows in Iceland.

356 Approximations, including treating lithosphereric deflection in terms of thin elastic plate

357 flexure, allow an analytic description of the shape of the contacts between flows and

358 between the flows and underlying dikes. The model geometry depends on two

359 independent length scales: the flexure parameter, $\alpha$, and the maximum isostatically

360 supported extrusive layer thickness, $w_{0}$ (Figure 3). For reasonable values of these

361 parameters the model reproduces the observed range of flow dip angles in SDRs.

362 A numerical scheme using these analytic results allows simulation of the effect of

363 temporal changes in the locus of magmatic spreading and the level of volcanic infill.

364 Either jumps in the location of the diking center or periods with no volcanism result in

365 separate units or "packages" of model SDRs, in which the flow-dike contact dips

366 landward, consistent with observations previously attributed only to listric normal fault

367 offset. When jumps are large compared to the flexural parameter the model reproduces

368 the pattern of flow units dips seen in abandoned spreading centers in Iceland (Hardarson

369 et al.; 1998; Figure 7). Several small magnitude jumps in the same direction produce the

370 kind of asymmetric SDRs seen across conjugate rifted margins of the South Atlantic

371 (Figure 6) and previously attributed to lithospheric scale detachment faulting (Becker et

372 al., 2016).

373 Magma intrusion and volcanism affect many rifts and continental margins but are ignored

374 in most numerical models of lithospheric extension, including recent studies (e.g. 
375 Svartman Dias et al., 2015; Brune et al., 2016). Only a few recent models include

376 idealized simulations of magma intrusion in long-term lithospheric extension models (e.g.

377 Bialas et al., 2010; Keller et al. 2013). The present work may stimulate development of

378 more complete numerical treatments of effects of rift magmatism, since such models can

379 be "benchmarked" against the analytic results given here.

\section{Acknowledgements}

381 Discussions with and comments from Xiaochuan Tian, Anthony Watts, James Pindell,

382 Sascha Brune and two anonymous reviewers greatly improved the manuscript.

383 Supported by National Science Foundation [Award 1009839].

\section{References}

385 Barton, A.J., and R. S. White (1997) Volcanism on the Rockall continental margin: Geol.

386 Soc. London, 154, 531-536, doi:10.1144/gsjgs.154.3.0531.

387 Bastow, I., and D. Keir (2011) The protracted development of the continent-ocean 388 transition in Afar: Nature Geoscience, v. 4, p. 248-250, doi:10.1038/ngeo1095.

389 Becker, K., D. C. Tanner, D. Franke, and C. M. Krawczyk (2016), Fault-controlled

390 lithospheric detachment of the volcanic southern South Atlantic rift, Geochem.

391 Geophys. Geosyst., 17, doi:10.1002/2015GC006081.

392 Bialas, R, W. R. Buck and R. Qin (2010) How Much Magma is required to rift a 393 continent? Earth and Planet Sci. Lett., 292, 68-78, 2010.

394 Bodine, J.H., M.S. Steckler and A.B. Watts (1981) Observations of Flexure and the 395 Rheology of the Oceanic Lithosphere, J. Geophys. Res., 86, 3695-3707. 
396 Bodvarsson, G. \& Walker, G. P. L. (1964) Crustal drift in Iceland, Geophys. J. R. astr.

$397 \quad$ Soc., $8,285-300$.

398 Brun, J. P. (1999), Narrow rifts versus wide rifts: Inferences for the mechanics of rifting

399 from laboratory experiments, Phil. Trans. R. Soc. Lond. A, 357, 695-712.

400 Brune, S., S.E. Williams, N.P Butterworth and D. R. Müller (2016) Abrupt plate

401 accelerations shape rifted continental margins, Nature, doi:10.1038/nature18319.

402 Buck, W. R.(2001), Accretional curvature of lithosphere at magmatic spreading produces

403 an elastically supported axial high, J. Geophys. Res., 106, 3953-3960.

404 Buck, W. R. (2004) Consequences of asthenospheric variability on continental rifting, in

405 Rheology and deformation of the lithosphere at continental margins, editors G.D.

406 Karner, B. Taylor, N.W. Driscoll and D.L. Kohlstedt, Columbia University Press, 1$407 \quad 31$.

408 Carbotte, S., A. Solomon, and G. Ponce-Correa (2000), Evaluation of morphological

409 indicators of magma supply and segmentation from a seismic reflection study of the

$410 \quad$ East Pacific Rise $15^{\circ} 30^{\prime}-17^{\circ}$ N, J. Geophys. Res., 105, 2737- 2759.

411 Coffin, M. F., and O. Eldholm (1994), Large igneous provinces: Crustal structure,

412 dimensions, and external consequences, Rev. Geophys., 32(1), 1-36,

413 doi:10.1029/93RG02508.

414 Corti, G., A. Agostini, D. Keir, J. Van Wijk, I. D. Bastow, and G. Ranalli (2015) Magma-

415 induced axial subsidence during final stage rifting: Implications for the development

416 of seaward-dipping reflectors, Geosphere, 11,DOI: 10.1130/GES01076.1.

417 Courtillot, V., C. Jaupart, I. Manighetti, P. Tapponnier, J. Besse (1999) On causal links 
418 between flood basalts and continental break-up, Earth Planet. Sci. Lett., 166, 177-

419195.

420 Einarsson, P. and B. Brandsdottir (1980) Seismological evidence for lateral magma

421 intrusion during the July 1978 deflation of the Krafla volcano in NE-Iceland, J.

422 Geophys., 47, 160- 165.

423 Franke, D. (2013), Rifting, lithosphere breakup and volcanism: Comparison of magma-

424 poor and volcanic rifted margins, Marine and Petroleum Geology 43, 63-87,

425 doi:10.1016/j.marpetgeo.2012.11.003.

426 Garcia, S., N. O. Arnaud, J. Angelier, F. Bergerat, and C. Homberg (2003), Rift jump

427 process in northern Iceland since $10 \mathrm{Ma}$ from $40 \mathrm{Ar} / 39 \mathrm{Ar}$ geochronology, Earth

$428 \quad$ Planet. Sci. Lett., 214, $529-544$.

429 Garcia, S., J. Angelier, F. Bergerat, C. Homberg, and O. Dauteuil (2008) Influence of rift

430 jump and excess loading on the structural evolution of Northern Iceland, Tectonics,

$431 \quad 27$, TC1006, doi:10.1029/2006TC002029, 2008.

432 Geoffroy, L., 2005, Volcanic passive margins: Comptes Rendus Geoscience, 337, 1395-

$433 \quad$ 1408, doi: $10.1016 / j$.crte.2005.10.006.

434 Gibson, I.L., D. Love (1989) A listric fault model for the formation of the dipping

435 reflectors penetrated during the drilling of hole 642E, ODP Leg 104, in: O. Eldholm,

436 J. Thiede, E. Taylor, et al. (Eds.), Proc. ODP, Sci. Results, 104, 979-983.

437 Hardarson, B.S., Fitton, J.G., Ellam, R.M., Pringle, M.S. (1997) Rift relocation - a

438 geochemical and geochronological investigation of a paleo-rift in northwest Iceland.

439 Earth Planet. Sci. Lett. 153, 181-196. 
440 Hey, R. N. (1979), Evidence for spreading center jumps from fine-scale bathymetry and 441 magnetic anomalies near the Galapagos Islands, Geology, 7, 504-506.

442 Hinz, K. (1981) A hypothesis on terrestrial catastrophes: wedges of very thick oceanward 443 dipping layers beneath passive margins - Their origin and palaeoenvironement $444 \quad$ significance, Geol. Jahrb., 22, 345-363.

445 Holbrook, W. S., and Kelemen, P. B. (1993) Large igneous province on the U.S. Atlantic 446 margin and implications for magmatism during continental breakup: Nature, 364 , $447 \quad 433-436$.

448 Hopper, J. R., J. T. Dahl, et al. (2003) Structure of the SE Greenland margin from seismic 449 reflection and refraction data; implications for nascent spreading center subsidence 450 and asymmetric crustal accretion during North Atlantic opening." J. Geophys. Res., $451 \quad 108: 2269$.

452 Huismans, R. S., S. J. H. Buiters, and C. Beaumont (2005), Effect of plastic-viscous 453 layering and strain softening on mode selection during lithospheric extension, J. $454 \quad$ Geophys. Res., 110, B02406, doi:10.1029/ 2004JB003114.

455 Keller, T., D. A. May, and B. J. P. Kaus (2013) Numerical modelling of magma 456 dynamics coupled to tectonic deformation of lithosphere and crust, Geophys. J. Int., $457 \quad 195,1406-1442$.

458 Keszthelyi, L. and S. Self (1998) Some physical requirements for the emplacement of 459 long basaltic lava flows J. Geophys. Res. 103,2156-2202 doi.org/10.1029/98JB00606.

460 Kusznir N. J. and R. G. Park (1984) Intraplate lithosphere deformation and the strength of 461 the lithosphere, Geophys. J. Roy. Astron. Soc., 79, 513-538. 
462 Larsen, H.C., et al. (1994) Proceedings of the Ocean Drilling Program, Initial Reports, 152, Ocean

463 Drill. Program, College Station, Tx.

464 Lavier, L., W. R. Buck and A.N. B. Poliakov (2000), Factors controlling normal faulting

465 in ideal elastic-plastic layers, J. Geophys. Res., 105, 23,431-23,442.

466 McKenzie, D. P. (1978) Some remarks on the development of sedimentary basins, Earth

467 Planet. Sci. Letts., 40, 25-32.

468 Mittelstaedt, E., G. Ito, and J. van Hunen (2011) Repeated ridge jumps associated with

469 plume-ridge interaction, melt transport, and ridge migration, J. Geophys, Res., 116, 470 doi:10.1029/2010JB007504.

471 Mohriak, W. U. and S. LeRoy (2012) Architecture of rifted continental margins and

472 break-up evolution: insights from the South Atlantic, North Atlantic and Red Sea-

473 Gulf of Aden conjugate margins, Geol. Soc. Lond., Sp. Pubs., 369:497-535, doi:

$474 \quad 10.1144 / \mathrm{SP} 369.17$

475 Mutter, J. M. Talwani, P.L. Stoffa (1982) Origin of seaward-dipping reflectors in oceanic

476 crust off the Norwegian margin by 'subaerial sea-floor spreading', Geology, 10, 353-

$477 \quad 357$.

478 Naliboff, J.B., Lithgow-Bertelloni, C., Ruff, L.J. \& de Koker, N. (2012) The effects of

479 lithospheric thickness and density structure on Earth's stress field, Geophys. J. Int., $480 \quad 188,1-17$.

481 Neilsen, T. F. D. and C. K. Brooks (1981) The E Greenland rifted continental margin; an

482 examination of the coastal flexure, Journal of the Geol. Soc. London, 138, 559-568.

483 Palmason, G. (1980) A continuum model of crustal generation in Iceland: kinematic 

aspects, J. Geophys., 47, 7-18.

485 Pindell, J., Graham, R., and Horn, B. (2014) Rapid outer marginal collapse at the rift to 486 drift transition of passive margin evolution, with a Gulf of Mexico case study: Basin $487 \quad$ Research, 26, 1-25, doi:10.1111/bre.12059.

488 Planke, S., P.A. Symonds, E. Alvestad, J. Skogseid (2000) Seismic volcanostratigraphy 489 of large-volume basaltic extrusive complexes on rifted margins, J. Geophys. Res., $490 \quad 105,19335-19352$.

491 Quirk, D.G., A. Shakerley, and M.J. Howe (2014), A mechanism for construction of 492 volcanic rifted margins during continental breakup, Geology, 42, 1079-1082, doi: $493 \quad 10.1130 / \mathrm{G} 35974$.

494 Rivalta E., B. Taisne, A.P. Bunger, R.F. Katz (2014) A review of mechanical models of 495 dike propagation: schools of thought, results and future directions, Tectonophysics $496638(2015) 1-42$, http://dx.doi.org/10.1016/j.tecto.2014.10.003.

497 Shah, A. and W. R. Buck (2003) Plate bending stresses at axial highs, and implications 498 for faulting behavior, Earth Planet. Sci. Letts., 211, 343-356.

499 Shah, A. and W. R. Buck (2006) The rise and fall of axial highs during ridge jumps, J. $500 \quad$ Geophys. Res., 111, B08101, doi:1029/2005JB003657.

501 Sibuet, J. C. (1992) New constraints on the formation of the non-volcanic continental 502 Galicia-Flemish Cap conjugate margins, J. Geol. Soc. Lond., 149, 829-840.

503 Siler, D. L., and J. A. Karson (2012), Subvolcanic subsidence and caldera formation 504 during subaerial seafloor spreading in Iceland, Geol. Soc. Am. Bull., 124(7/8), 1310$505 \quad 1323$, doi:10.1130/B30562.1. 
506 Svartman Dias, A. E., L. L. Lavier and N. W. Hayman, 2015, Conjugate rifted margins

$507 \quad$ width and asymmetry: The interplay between lithospheric strength and

508 thermomechanical processes, J. Geophys. Res., 120, 2015JB012074, doi:

$509 \quad 10.1002 / 2015 J B 012074$.

510 Watts, A. B. (2001) Isostasy and Flexure of the Lithosphere, Cambridge University

$511 \quad$ Press, $458 \mathrm{p}$.

512 Watts, A. B. and K. G. Cox (1989) The Deccan Traps: An interpretation in terms of

513 progressive lithospheric flexure in response to a migrating load, Earth Planet. Sci.

$514 \quad$ Lett., 93, 85-97.

515 White, R. S., and McKenzie, D. (1989) Magmatism at rift zones: The generation of

516 volcanic continental margins and flood basalts: Journal of Geophysical Research, 94, $517 \quad 7685-7729$, doi:10.1029/JB094iB06p07685. 


\section{Figure Captions}

519

520 Figure 1. (A) Location map of well documented volcanic rifted margins (red lines from

521 Geoffroy, 2005) and the locations of the multichannel seismic (MCS) reflection lines

522 shown below the map and in Figure 6. B shows MCS data from the East Greenland

523 Margin (from Hopper et al. (2003). C shows MCS data form the Exmouth Plateau of

524 Australia showing the 3 separate overlapping SDRs 'units' indicated with colored

525 shading (from Planke et al., 2000). The top of volcanic sequence is labeled ' $t$ ', prominent

526 reflectors dividing the sequence into sub-units are labeled ' $r$ '. D show MCS lines on the

527 Argentinean side of the South Atlantic and E shows similar data from the conjugate

528 margin the South Africa with lines and letters representing interpreted boundaries

529 between flow units (from Becker et al., 2016).

530

531 Figure 2. Illustration of two models for producing separate seaward dipping reflector

532 "packages" on a volcanic rifted margin. (A) shows the fault infill model (after Geoffroy,

533 2005) and (B) the volcanic flexure model, both described in the text. Light lines denote

534 volcanic flow tops and each color is meant to represent a sequence of flows formed

535 during a given time interval. The nail on the right of the panels indicates a frame of

536 reference in which the right margin is fixed.

538 Figure 3. Illustration of the volcanic flexure model for the development of SDRs. Panel

539 (A) shows a dike filled with fluid magma open between two lithospheric plates. The

540 density increase caused by solidification of the dike in (B) loads and bends the plates. 
541 Panel (C) shows how extrusion of magma amplifies the deflections. The results of 2 dike

542 intrusion plus extrusion events is shown schematically in (D). The size of dikes and flows

543 is exaggerated in A through D. (E) shows the results of many small dike intrusion plus

544 extrusion events and emphasizes that the model depends on two length scales, $\alpha$ and $\mathrm{w}_{0}$,

545 described in the text.

546

547 Figure 4. Plots of the analytically computed positions of a series of volcanic layer tops

548 (grey lines) as well as the location of the dike-flow contact (a black line) for the analytic

549 volcanic flexure model described in the text.

551 Figure 5. Results of three model cases that illustrate some of the diversity of SDRs that 552 can result from volcanic flexure. As in Figures 1 and 2 the lines dipping toward the 553 spreading axis, where distance $=0$, repret the tops of flow units. The same values for

554 flexural parameter $(\alpha=20 \mathrm{~km})$ and characteristic deflection $\left(\mathrm{w}_{0}=10 \mathrm{~km}\right)$ were used for

555 all cases. (A) shows the model flow geometry after a total of $60 \mathrm{~km}$ of plate separation

556 ( 30 on each rift side) with a fixed location of the center of diking intrusion with extrusion

557 constantly filling the flexural low. (B) shows asymmetry in the horizontal distribution of

558 SDR packages due to a sequence of periods each with $40 \mathrm{~km}$ of spreading followed by a

$55910 \mathrm{~km}$ leftward jump in the spreading center. (C) shows how periods with $40 \mathrm{~km}$ of

560 spreading and extrusion followed by a "gap" with $20 \mathrm{~km}$ of dike accommodated

561 spreading without volcanic extrusion, can result in distinct SDR packages.

562

563 Figure 6. A and B show interpreted MCS lines (with depth sections based on refraction 
564 data) on conjugate margins of the South Atlantic and letters represent boundaries between

565 flow units (from Becker et al., 2016). The interpreted SDR packages are thicker and

566 narrower on the western (South American) margin than the eastern (African) margin. C

567 Shows the predicted extrusive layer geometry resulting from the volcanic flexure model

568 described in the text. For that model case the flexure parameter $\alpha$ is $20 \mathrm{~km}$, the

569 characteristic volcanic layer thickness $w_{0}$ is $12 \mathrm{~km}$. The parameters on the lower right

570 side of the plot describing the sequence of 3 periods normal extrusion for $10 \mathrm{~km}$ of

571 spreading followed by a gap of $5 \mathrm{~km}$ with no extrusion then a $5 \mathrm{~km}$ jump to the left.

572

573 Figure 7. Map at top shows the positions of present and past (dotted lines) regions of

574 volcanism and focused plate separation for Iceland (from Hardasson et al 1997). The

575 present Northern, Middle, Western and Eastern Rift Zones are labeled accordingly. The

576 approximate age range of past spreading and volcanic activity are shown adjacent to the

577 dotted lines. The sequence of model results shown below indicate the effect of several

578 large jumps (jump distance $>\alpha$ ). 
Fluid magma filled dike intrudes crustal lithosphere

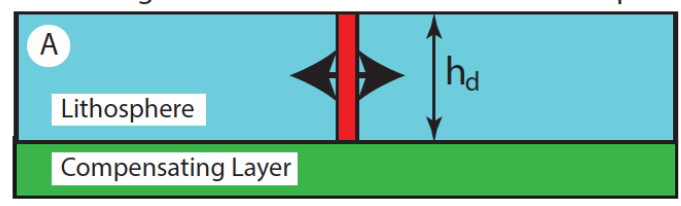

Solidification of dike loads lithosphere

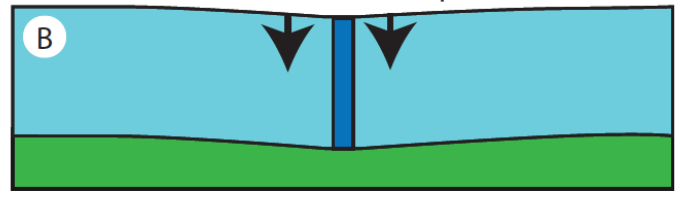

Extrusives further load lithosphere

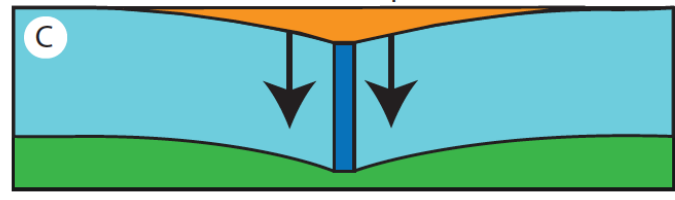

Repeat A, B, C\& A
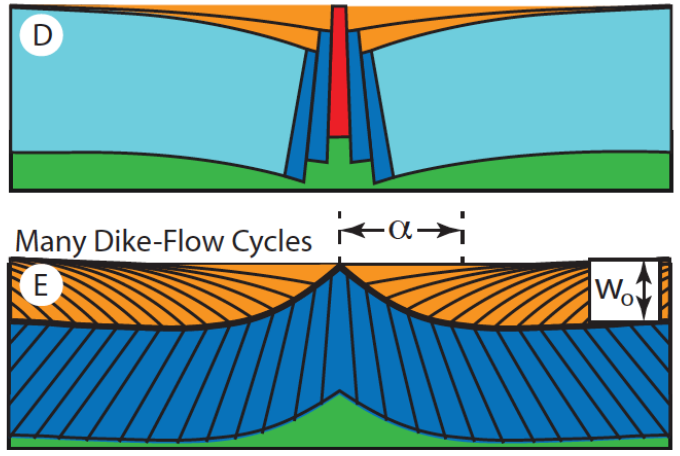

Fluid Dike

density $\rho_{f}$

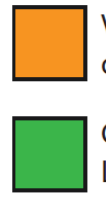

Volcanic Infill density $\rho_{\mathrm{i}}$

Compensating Layer, density $\rho_{\mathrm{s}}$

Illustration of the volcanic flexure model for the development of SDRs. Panel (A) shows a dike filled with fluid magma open between two lithospheric plates. The density increase caused by solidification of the dike in (B) loads the bends the plates. Panel (C) shows how extrusion of magma amplifies the deflections. The results of 2 dike intrusion plus extrusion events is shown schematically in (D). The size of dikes and flows is exaggerated in A through D. (E) shows the results of many small dike intrusion plus extrusion events and emphasizes that the model depends on two length scales, $\alpha$ and $w_{0}$. 
(A) Volcanic Rifted Margins

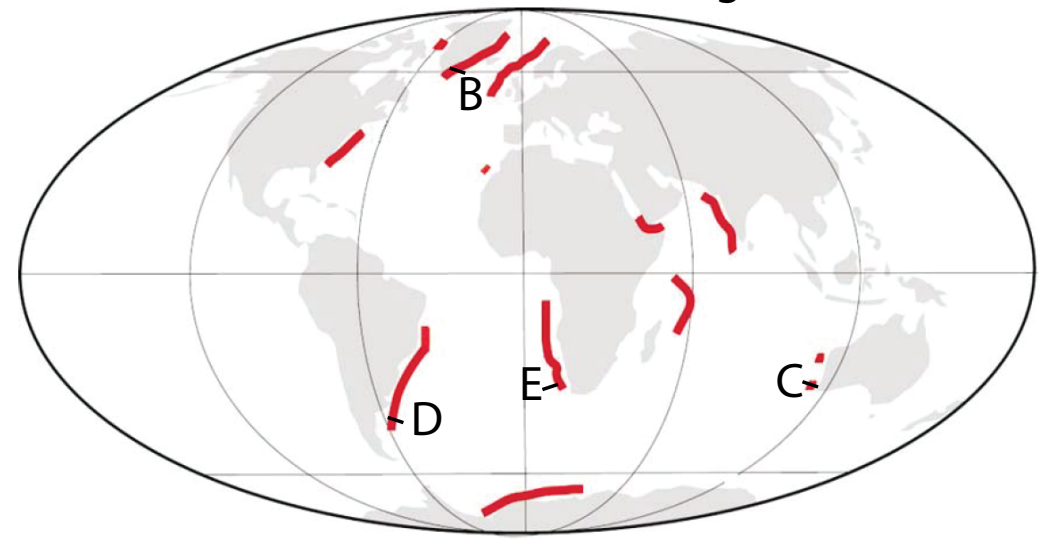

(B) East Greenland Margin

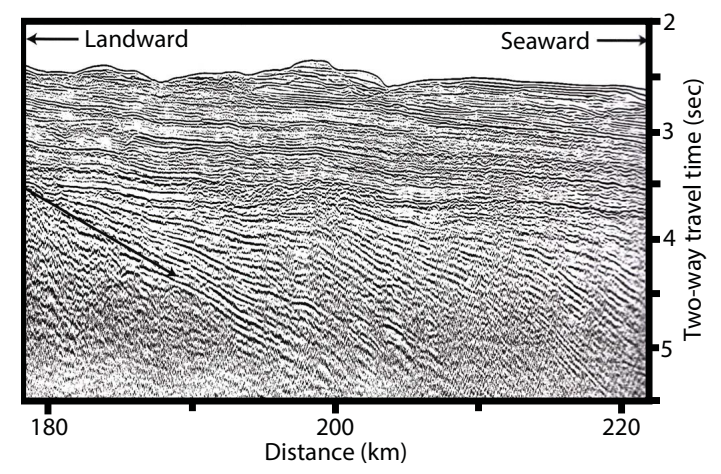

(C) Western Australian Margin

(D) South American Margin
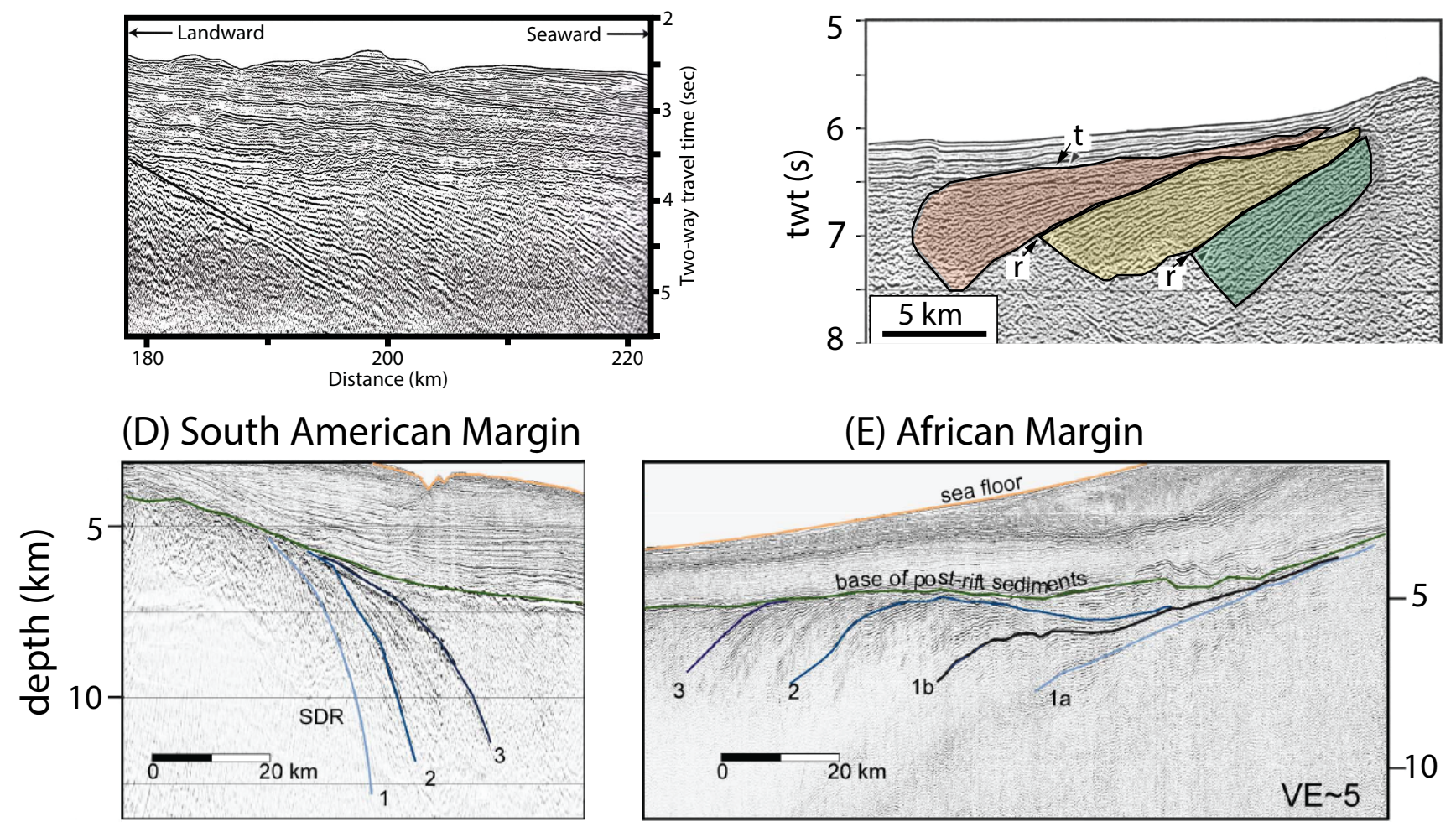

(E) African Margin

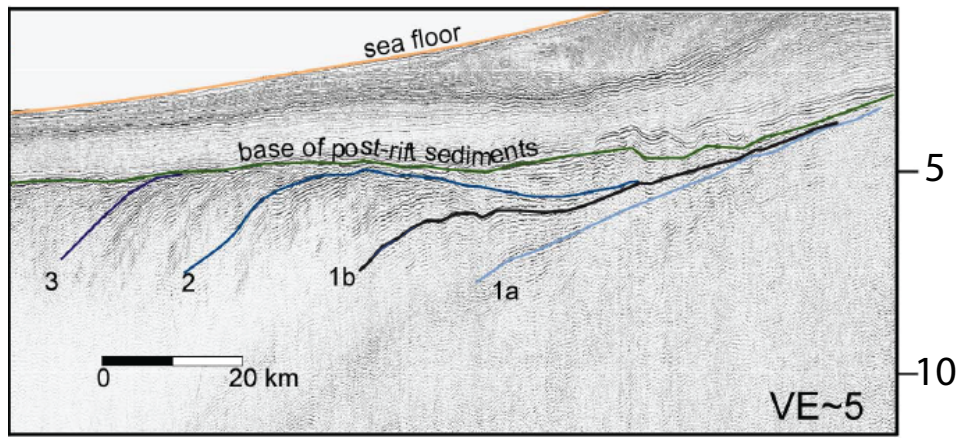

Figure 1. 
A. Faulting with Volcanic Infill
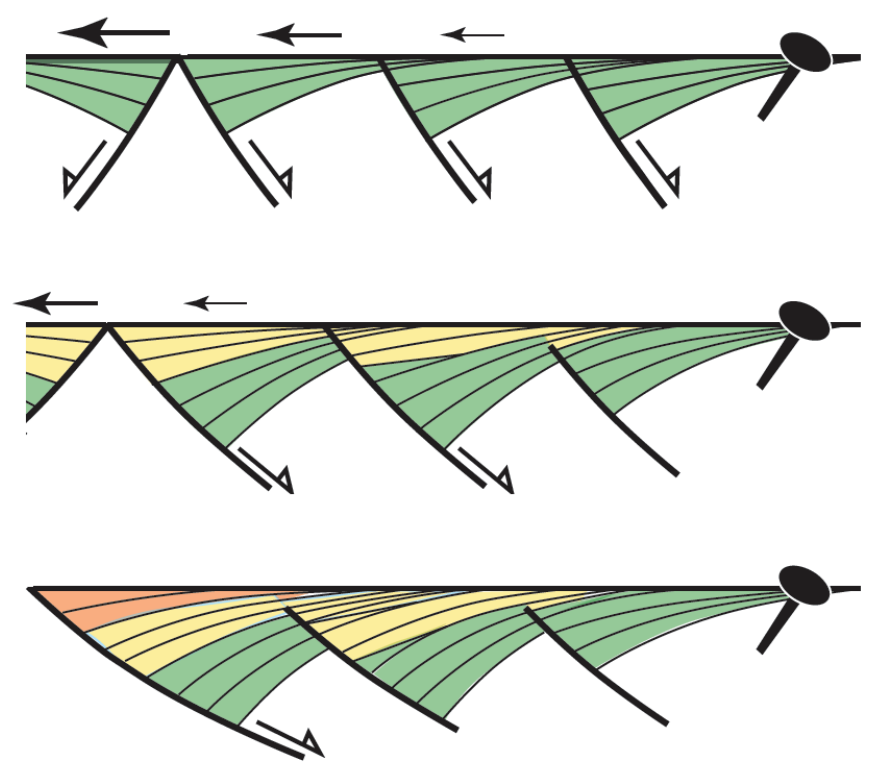

B. Volcanic Flexure with Jumps
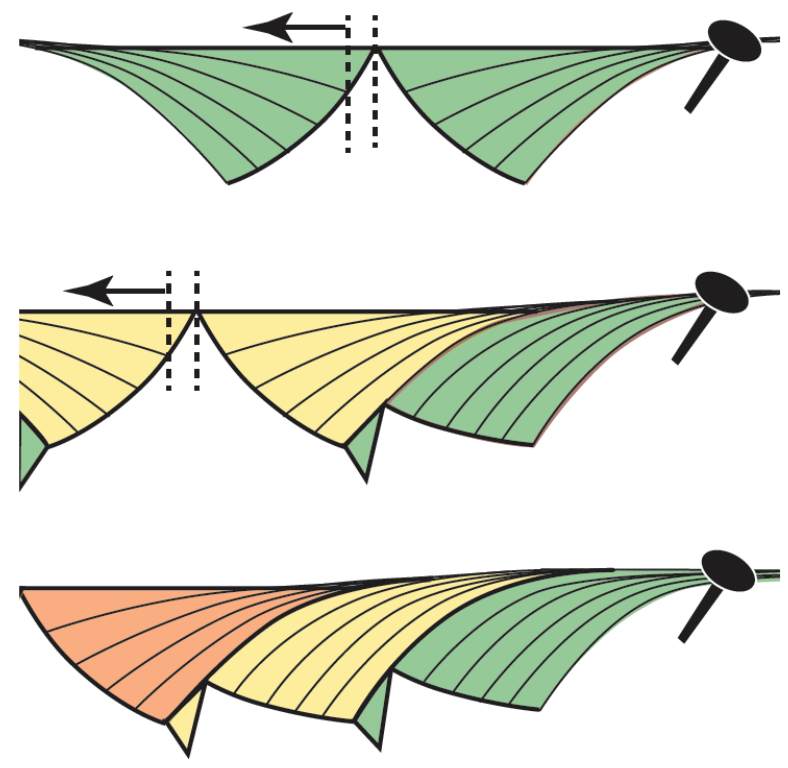

Figure 2 
Fluid magma filled dike intrudes crustal lithosphere

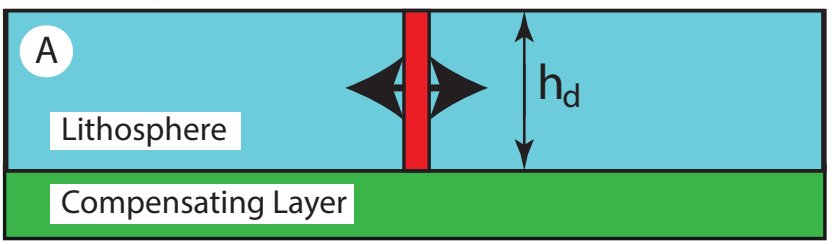

Solidification of dike loads lithosphere

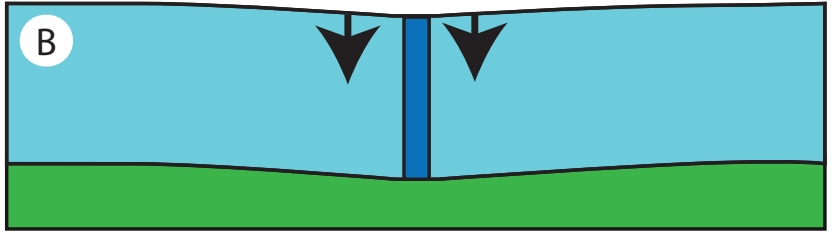

Extrusives further load lithosphere

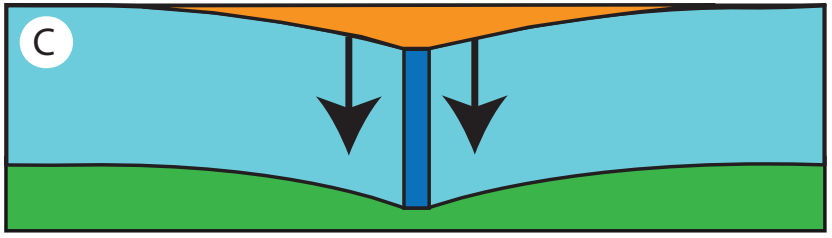

\section{Repeat A, B, C\& A}
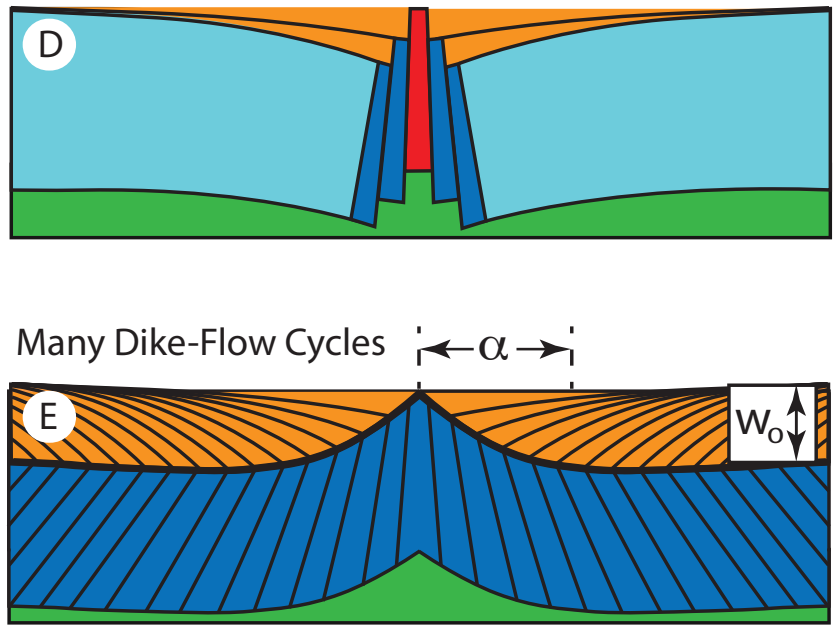

Fluid Dike density $\rho_{f}$

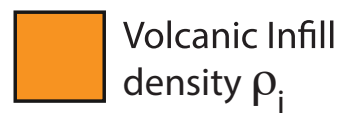

Solid Dike density $\rho_{d}$

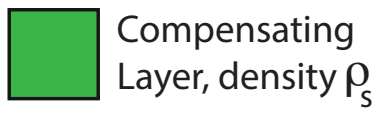




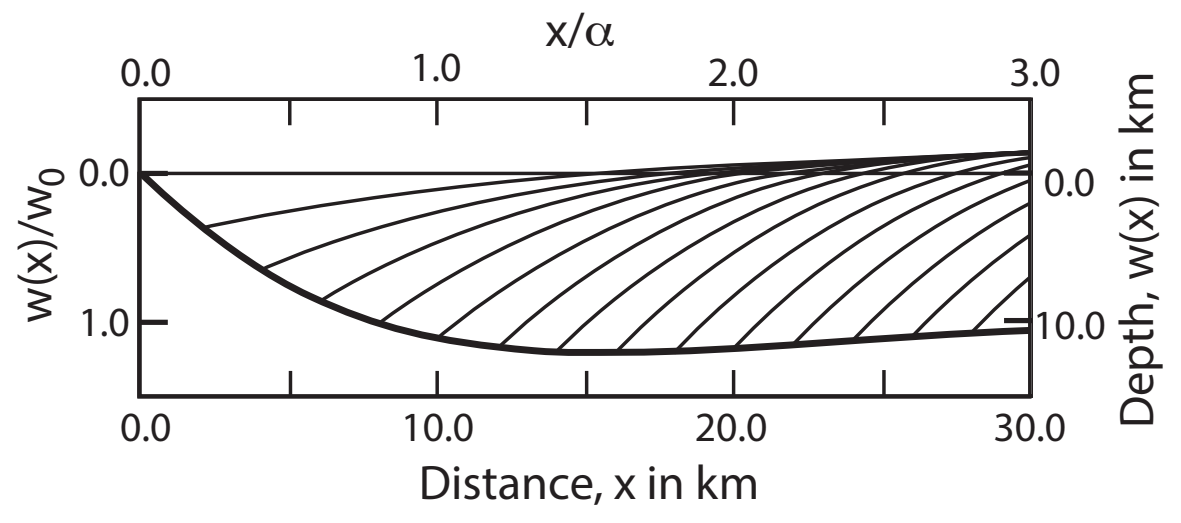

Figure 4. 

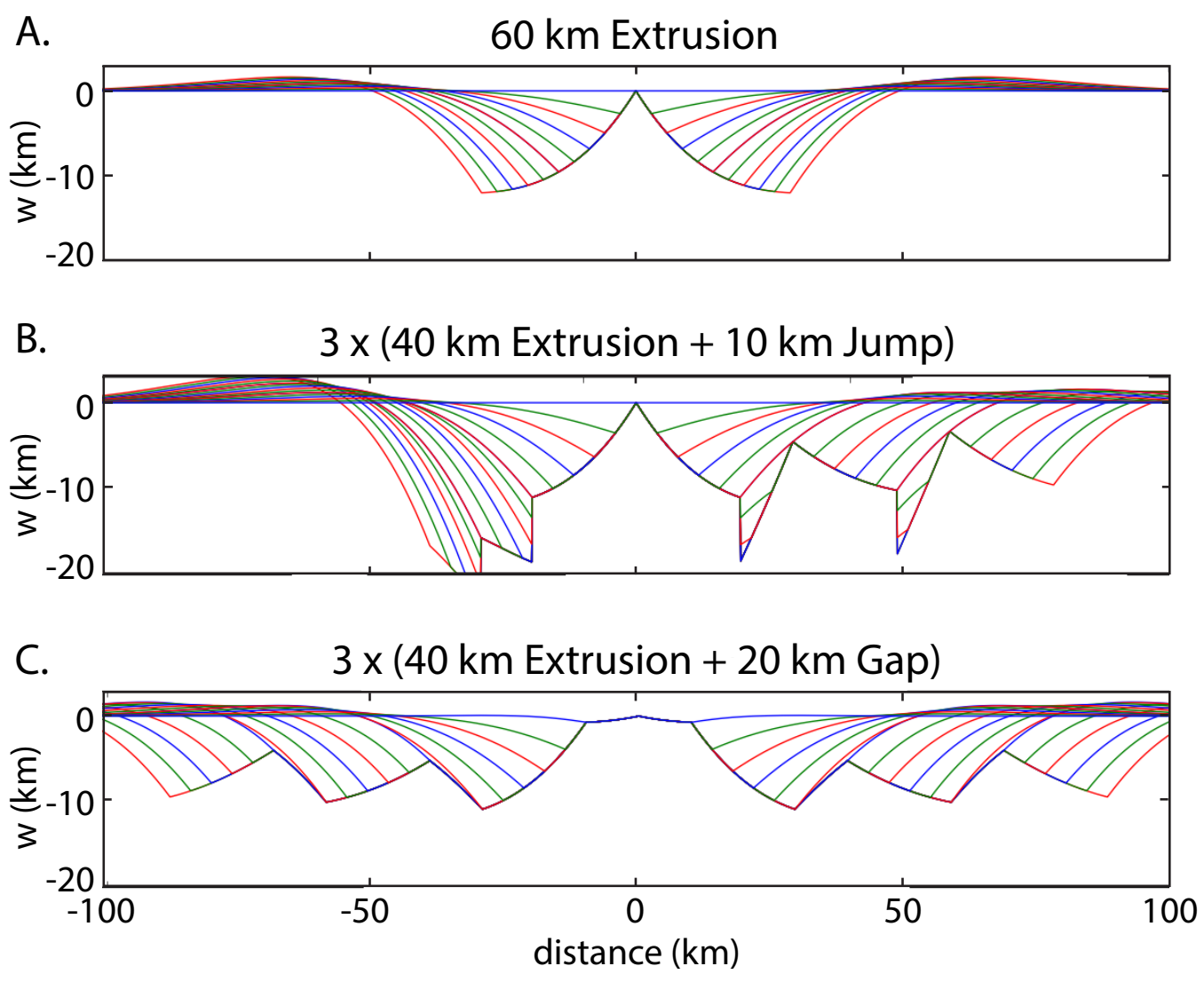

Figure 5. 

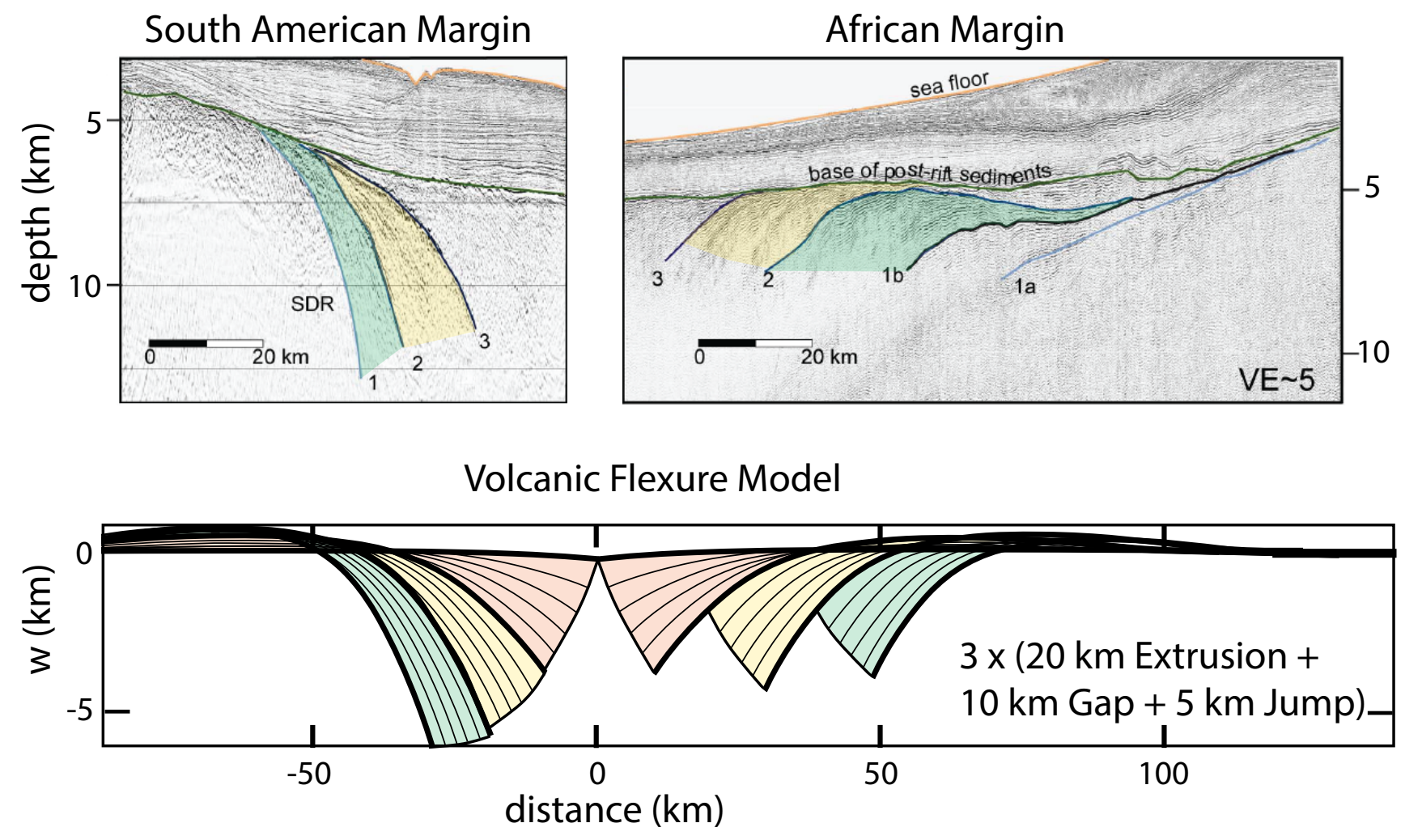

Figure 6. 

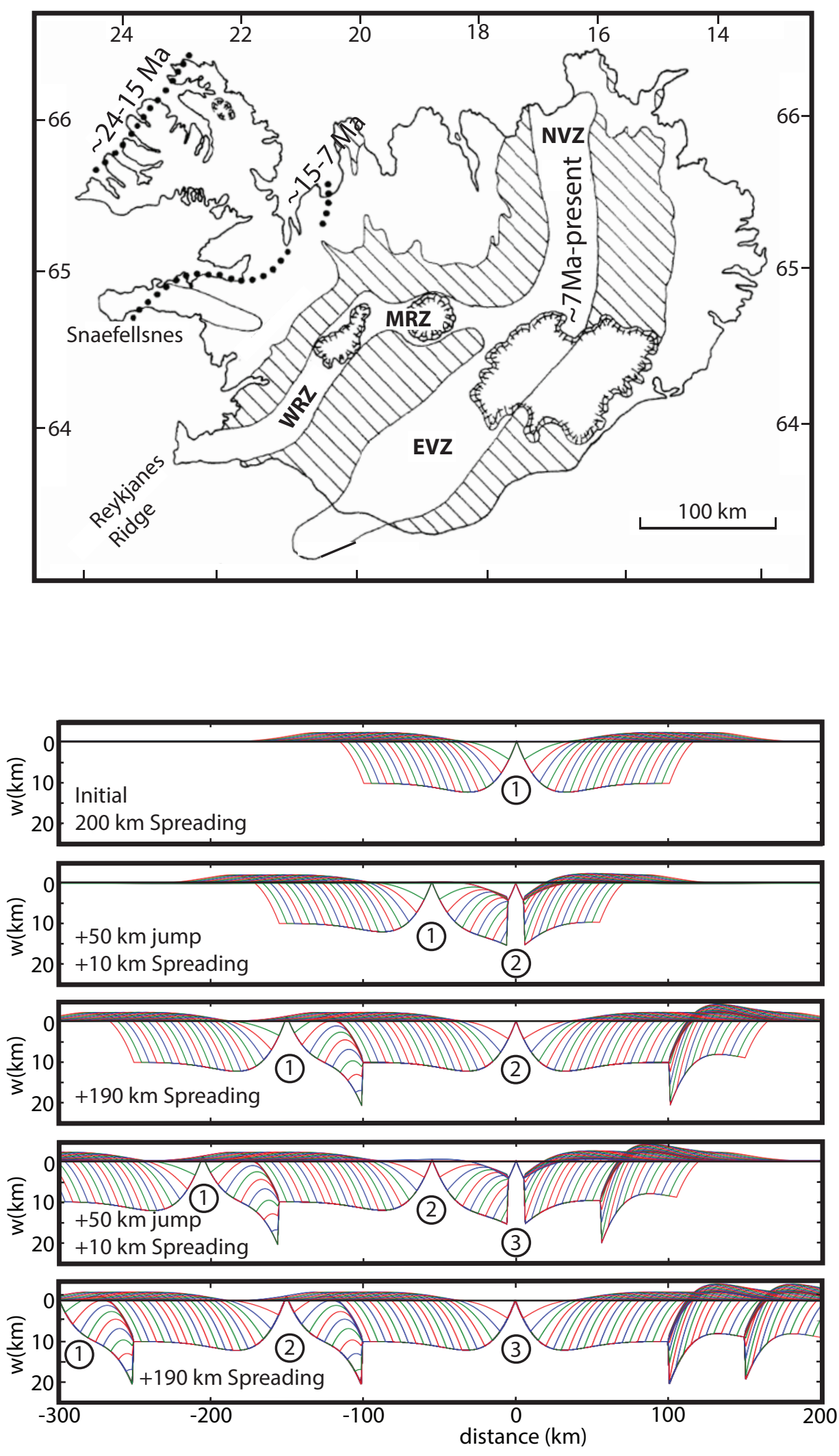

Figure 7. 